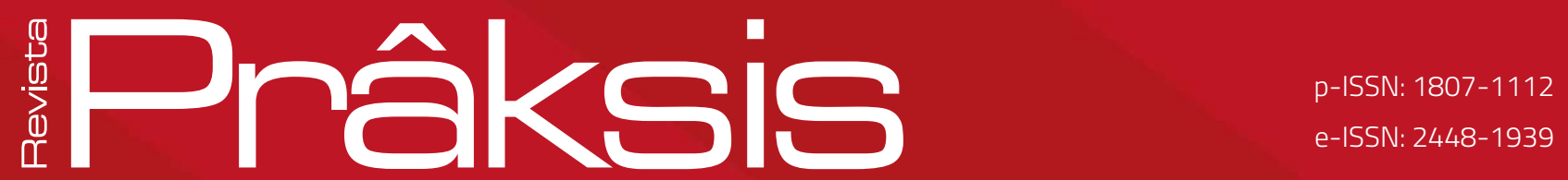

Recebido em: 03 de março de 2019

Aprovado em: 15 de julho de 2019

Sistema de Avaliação: Double Blind Review

RPR |a. $16 \mid$ n. 3 |p. 53-66| set./dez. 2019

DOI: https://doi.org/10.25112/rpr.v3i0.1979

\title{
COMPARATIVE STUDY OF HOME CARE DIGITALIzATION FOR ELDERLY PEOPLE IN BRAZIL AND FINLAND
}

\section{ESTUDO COMPARATIVO DA DIGITALIZAÇÃO} DOMICILIAR PARA IDOSOS NO BRASIL E FINLÂNDIA

\section{Minna Korpela}

E-mail: minna.korpela87@gmail.com

\section{Piia Holmström}

E-mail: holmstrompiia@gmail.com 


\section{ABSTRACT}

This thesis describes health care services for elderly people in Finland and Brazil, as well as health technology in both countries. The aim of the thesis is to provide information on the health technology for the elderly and to bring out their opinion about the need for digital services and what kind of digital solutions they would find useful as they get older. Our thesis is a qualitative research in which the observation material is in form of a questionnaire. The material is compared between the target countries. The target group is people who are over 75 years old in Finland and over 65 years old in Brazil and who are still living at home. The main objective is to identify the need for digital health services and solutions expressed by elderly citizens living in Brazil and Finland. Our research tasks: What kind of digital services home living elderly over 75 years old in Finland and over 65 years old in Brazil think it might be useful in connection with their health care? What kind of health services and digital solutions have an offer in Brazil and Finland? How is customer- oriented service implemented with digital solutions? According to the results, both in Finland and Brazil, elderly people felt that technology could be useful in terms of access to information and security and they were looking for ways to get help in everyday activities. In Finland, more technological solutions were available than in Brazil for healthcare.

Keywords: Digitalization. Ethics. Succesful aging.

\section{RESUMO}

Esta tese descreve os serviços de saúde para idosos na Finlândia e no Brasil, bem como a tecnologia em saúde nos dois países. $\mathrm{O}$ objetivo da tese é fornecer informações sobre a tecnologia de saúde para idosos e expor suas opiniões sobre a necessidade de serviços digitais e que tipo de soluções digitais eles acham úteis à medida que envelhecem. Nossa tese é uma pesquisa qualitativa na qual o material de observação é em forma de questionário. 0 material é comparado entre os países-alvo. 0 público-alvo são pessoas com mais de 75 anos na Finlândia e com mais de 65 anos no Brasil e que ainda moram em casa. 0 objetivo principal é identificar a necessidade de soluções e serviços digitais de saúde expressos por idosos residentes no Brasil e na Finlândia. Nossas tarefas de pesquisa: Que tipo de serviços digitais para idosos que têm mais de 75 anos na Finlândia e mais de 65 anos no Brasil acham que pode ser útil em conexão com seus cuidados de saúde? Que tipo de serviços de saúde e soluções digitais oferecem no Brasil e na Finlândia? Como o serviço orientado ao cliente é implementado com soluções digitais? De acordo com os resultados, tanto na Finlândia quanto no Brasil, os idosos sentiram que a tecnologia poderia ser útil em termos de acesso à informação e segurança e estavam procurando maneiras de obter ajuda nas atividades cotidianas. Na Finlândia, mais soluções tecnológicas estavam disponíveis do que no Brasil para a saúde.

Palavras-chave: Digitalização. Ética. Envelhecimento bem-sucedido. 


\section{INTRODUCTION}

The population is ageing all over the world. Fast-paced ageing has also an impact on services for the elderly. Living at home is supported, the goal being that $90 \%$ of people over the age of 75 years could live in a regular home. It is believed that a motivated elderly person will be able to survive with the help of developed technology and modern living conditions at home.

In Brazil, the demographic structure changed in 1970-2000; the share of aging population increased from $55.9 \%$ to $80 \%$. Brazil is the world's fifth most populous country. Brazil has been developing since 1988 a dynamic and complex healthcare system, which consists of citizen's right and the obligations of states. Most of the elderly in Brazil live at home. In order to provide health services, it is good for people to have insurance in order to better secure the quality of care. There are no public home health care or technology solutions in Brazil yet (PAIM; TRAVASSOS; ALMEIDA; BAHIA; MACINCO, 2011).

Technology and services are being developed extensively. The development of welfare technology aims at the prevention of physical, mental and social impairment as well as compensation for functional disadvantages, making the social and health care services more effective. The younger an elderly person is, the more likely she or he will believe that technology is useful. Yet still many elderlies also experience disfunction and lack of motivation for use of technology. Many elderlies need more guidance and alternatives to technological services as they face challenges with learning, physical functions, especially vision, as well mobility of the joints and weakening of muscular strength. All these factors affect the use of technical equipment.

At this stage, there is only a small amount of compiled information and studies available about the elderly and their use of technology. The European union has actively supported research on elderly, technology and product development, through research networks and research programs (HEIKKINEN; JYRKÄMÄ; RANTANEN, 2013).

\section{HUMAN AGEING}

Human ageing is a whole life process at different levels. Some changes are more visible than others and there is considerable individual variability. No two people age alike. Age-related changes are also felt at functional and physiological levels. It is a part of normal ageing that the ability to perform physical tasks declines with age. Also, as part of normal ageing are loss of muscle and bone mass and weight loss in general. Some physiological and functional hallmarks of ageing include a lower metabolic rate, height loss, longer reaction times and decreased sexual activity. As to women, menopause or inability to 
reproduce is an inevitable consequence of old age. Deterioration of activity can be seen with functional declines in kidney, pulmonary and immune functions. The main concern for older adults is mental health since memory and cognitive impairment are part of human ageing (PEDRO DE MAGALHÃES, 2012).

There are many different theories about ageing. First of all, there is an evolutionary theory of ageing and two main models exist for explaining the evolution of ageing. According to the first model harmful late-acting mutations accumulate because they are beneficial at earlier ages. These two models compose the classical evolutionary theory of ageing. The evolutionary theory of ageing is one of the theoretical landmarks of biogerontology (PEDRO DE MAGALHÃES, 2012).

\subsection{ETHICS AND TECHNOLOGY}

Today, definition of ethics and values is closely related to technology. Different questions and perceptions of what is to be desired, permissible or forbidden will arise, especially in the context of technological advances and scientific breakthroughs. For example, in the social and health care sector, technology can help to improve the life management and health care of healthcare users, streamline the work of professionals, and facilitate the organization's operations and access to information. Technology covers broadly all the technical solutions, design, development, use and evaluation of information related to health, management and related in-formation, as well as information management issues and the ethical basis of information management professionals (PIRHONEN, 2016).

Often, technology for older people is considering what kind of technology is appropriate, good and functional for the elderly. The use of technology is always driven by human values and the choice of technology. Elderly people have their own world of value in using technology and very often the choice is made by close ones, a trustee or a social and health professional, such as a nurse. Then their values will also be the basis of their choices. This raises the question of whether it is ethically correct if it is chosen on behalf of another person and whether it is good for the user of the technology. Unfortunately, however, often the economic advantage wins over the desire of the elderly and the possibility of using the technology is easily forgotten. However, in order to learn how to use technology correctly, the elderly have the right to guidance and counseling. The choice of technological solutions should always consider individuality and the ability of the customer to act (ÄIJÖ; TIKKANEN, 2019).

Ethical questions focus on two different levels, descriptive and guiding levels. The descriptive levels tell you what is good and what is bad. The guiding level tells you how to act correctly and what behaviour is wrong. Ethical issues related to health technology include, for example; why technology is used, how it is used, how technology is evaluated, and whether the nursing professionals' techno-logical-ethical 
competence is enough. The use of technology involves key ethical principles in nursing, such as patient respect, self-determination and support, privacy and fairness among patients (PIRHONEN, 2016).

In most cases, the use of technology is welcomed. It is thought to be a good thing for either a patient, a professional, an organization or the whole healthcare system. It aims to make work more accurate, more re-liable, and it is thought to save and direct the human resources of a professional and maintain up-to-date follow-up. The problem may be that the introduction of technology generally requires a lot of investment and resources, needs to be trained and maintained. Ethically, it is essential that the technology is put in place in good time and that the goal of technology is known to everyone involved. Work-related impacts must also be visible. For example, it is important for nurses to have a human contact with a patient, and technology does not violate the basic values of nursing (PIRHONEN, 2016).

\subsubsection{ELDERLY AND TECHNOLOGY}

The internet can be used to fight loneliness and feeling of helplessness. However, internet may also affect negatively on well-being of an individual. Time spent with strangers on the internet takes time away from other activities and the elderly may sense a lack of social contacts. In a best possible way, internet can bring emotional success to the elderly, which is an effective way to reduce depression and enhance self-esteem (KORPELA, 2018).

Video technology was the most commonly used form of home health care technology in 2013 . Video technology can be used to guide the elderly to use technological equipment or, for example, to arrange meetings between a patient, healthcare personnel and relatives. Video technology enables meetings at home. Elderly people or healthcare personnel need not move from place to another just because of meetings (GARDEMEISTER, 2018).

At this point, most home health care clients are examined in the hospital or with the help of devices that can be imported home. In the future it could be possible to continuously collect health data through monitoring from home health care clients. Monitoring could be used, for example, to send data about health to health professionals to be analyzed, these could be weight, blood pressure and pulse. In the future, health technology services are needed to treat patients more effectively, also focus on predicting the development of potential diseases and anticipate treatment in good time (GARDEMEISTER, 2018).

The teknology brings with it solutions that reduce age-related constraints, as the elderly also wants to continue with important hobbies and leisure time. For example, audiobooks can be the solutions if reading itself is no longer successful or if the hearing is impaired, then wireless headphones allow you to watch TV (ÄIJÖ; TIKKANEN, 2019). 


\section{METHODOLOGY}

Qualitative research aims at describing real life, finding facts and exploring the subject as much as possible. In qualitative research, reality is diverse, but it cannot be arbitrarily divided into small parts. The researcher must adhere to the value points of the research, because we are trying to understand the phenomena that are being studied (HIRSJÄRVI; REMES; SAJAVAARA, 2009).

Our thesis is a qualitative research, where the observation material is collected by a questionnaire (the questionnaire was translated into Portuguese in Brazil). We are searching information about digital solutions effectiveness and opportunities in elderly home health care. We are making comparative research between Finland and Brazil. The target group is elderly, which are over 75 years old in Finland and over 65 years old in Brazil and they are still living at home. Questionnaires are made for a six elderly in both countries, altogether for twelve people.

We chose a qualitative approach to our research because we wanted to get older people's own opinions and feelings about the topic. Our study has two target countries where older people were interviewed, so we compared the views and responses of the elderly in the target countries. We focused on examining whether there is a difference in technology knowledge among older people, and whether there is a difference in internet and technology between women and men.

In our study, we used a theme interview. The theme interview is a form of open and formal interview. In this interview, it is typical that topics are known, but the exact form and order of the questions are missing. Theme interviewing is a good starting point for many qualitative researches, although not exclusively a qualitative method. The material obtained can be analyzed and interpreted in many ways. In this work, we conducted interviews as an individual interview (HIRSJÄRVI; REMES; SAJAVAARA, 2009).

Through the theme interviews, we strive to answer the research questions. In the first question about health technology knowledge, we wanted to lead the subject and hear about their knowledge of technology. In the next question, we wanted the participants to tell us what type of technological aid they know. We also used examples of these tools in this question because we wanted them to understand what kind of technology is involved. In the third and final question, we wanted not only hear about the information used by the elderly but also their ideas and what types of health technology solutions they would feel useful in their lives and home conditions now or in the future. We felt that the last question was very important because it brought up best the older person's own opinion on technology. Through the interview, we found answers to our research questions.

We decided to take the interviewees' age as one of the limits to the research group. In Brazil we cut the age to over 65 and in Finland to over 75 years old. The ten-year gap between target countries is due 
to differences in life expectancy and different health situations. In Finland's life expectancy comparison table Statistics Finland, life expectancy in 2017 is 81 years, while in Brazil 76 years. (TILASTOKESKUS, 2018; KNOEMA n.d.) In 2017, the life expectancy of newborn girls in Finland was 84,2 years and for boys 78,7 years (TILASTOKESKUS, 2018). In Brazil, life expectancy in 2016 for women was 79.14 years and for men 71.88 years (COUNTRYECONOMY, n.d.).

\section{RESEARCH RESULTS IN FINLAND}

The participants are from Brazil, Novo Hamburgo and Lahti, Finland. Interviews were conducted in both Brazil and Finland for six people. There were four women and two men in Brazil. The youngest interviewees in Brazil were 67 years old and the oldest 76 years old. In Finland, two of the interviewees were also men and four women. The youngest interviewees in Finland were 75 years old and the oldest 83 years old. In Finland, the language was Finnish and in Brazil Portuguese. The interviews were carried out in Brazil in a senior activity center and in Finland in the interviewee's own home.

In both target countries, interviews were based on people's volunteering, so they signed the interview consent forms. In Brazil, interviewees were selected by a university research team and interviewed by older adults in Portuguese who returned their replies by email in English. In Finland, the target population was selected from the local congregation in Lahti, where a related person made a preliminary survey of the volunteers to be interviewed and gave their contact details with their permission. In the Finnish interviews, both authors of the thesis were present. In Brazil, all the individuals were involved in recreational activities. In Finland, two of the interviewees were couples and two widows.

Half of the interviewees in Finland said they had heard about health technology. However, two interviewees, who replied that they had not heard, were able to list a few health care technological aids. In Finland, 2 men (out of 2) reported having heard about health technology and one woman (out of 4) one said she had heard about health technology. One male respondent wondered what health technology was and answered as follows:

"It also includes science, not just technology, and also the professionals' understanding." (6)

All but one of the respondents knew how to name a health care technical aid. Four out of six respondents mentioned a telephone. Mobile phone applications seemed unknown. One of the respondents had familiarized himself with remote treatment in a friend's home, i.e. a tablet with which he could contact a nurse, for example. He replied as follows:

"I've seen a tablet application at a friend's house, which has the connection to e.g. nurses. "(2)

One of the participants also mentioned that a doctor can now be contacted. Three female respondents 
knew the drug dispenser, which reminds one to take drugs on time. One female respondent was able to tell about an application where you can choose the person to whom the application is calling in case of problems. One respondent felt that he needed guidance, for example, on the use of the tablet. However, the respondent said he had been on a computer course once and had a smartphone and tablet in use. One female respondent was able to tell about her own app. One male respondent said he didn't know about mobile phone applications. He said he had a caterpillar cellphone in use and felt that it wasn't that modern. The respondent felt that the touch screen was beyond his understanding. He also felt that the necessary phone numbers should be saved on the phone. The respondent considered the hearing aid as an important technological aid because he used to sing.

When asked about a useful health technology solution at home, everyone except one participant came up with a type of solution that would benefit them. None of the respondents felt that they needed any technological aid, but they wondered what might be needed in the future. One of the participants had a rather negative attitude towards technology. She was a woman with visual disability living alone. The woman replied as follows:

"All of them cost and when there is a small pension, there is no way to think of the solution I would like. Life is mechanized. Humanity? It's even scary if you don't get human contact, only robots." (1)

One male participant also felt that he would prefer to talk directly to a person, rather than through any application, but was able to name several technological aids for him and was particularly interested in acquiring a smart watch capable of monitoring sleep and heartbeat.

Two of the participants would find the safety telephone useful and the other two participants said that healthcare was remotely useful. They said:

"How to get into contact with someone? (ask a person)." (3)

"That would get a direct link to the nurse with a video link." (4)

One male participant felt that the computer was also a tool in some way and that the computer turned the writing into sound. However, the same participant felt that he was getting the best protection and help from going to the emergency room or hospital for help. He replied

"As long as you can drive a car, it's easy. There is no substitute for understanding. If understanding is preserved, you know what you need." (6)

Another male participant experienced the following about technology:

"Maybe the results of the tests could be sent through the application to healthcare." (2)

One female participant wondered if a stove that would turn itself off would be useful in the future. The same participant would find a cleaning robot useful. Otherwise, she hoped she could find useful 
technological help in the future. She also felt that it would be good to find out about the different possibilities and to be open to them. One of the female participants had experience of mobility aids, such as the use of an electric bike. She also felt the need to have a phone and the necessary contact information. She felt that text magnifying devices would be useful in the future. One male respondent also felt the need for mobility aids in the future, especially indoors. One respondent mentioned that people living in Lapland and his grandchildren also get help with technology. There is a computer, a landline telephone, and a cellphone for that participant couple. (Table 1).

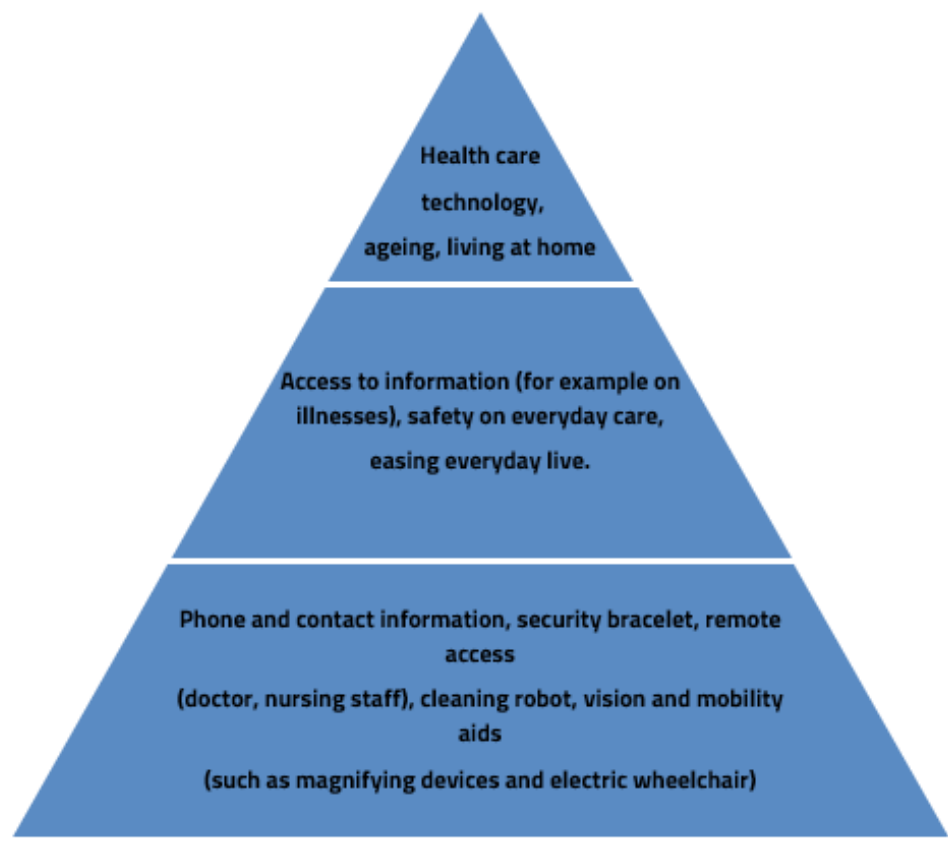

Table 1. Analysis of Finland

\section{RESEARCH RESULTS IN BRAZIL}

Four out of six participants said they had heard about healthcare technology. One woman and one man reported that they had not heard of health technology. One woman told that she knew image exams and video surgery.

Only one of the participants said he knew basic mobile phone applications. No other participants knew any mobile phone applications. However, one of the participants said that she knew several monitoring applications. One female participant said:

"I don't know any cell phone applications, but I'm in a group of a preven-tive medicine (Cooperativa 
Unimed), that pays home visits at 3-month in-tervals. The nurse takes notes and analyses the laboratory tests and checks the arterial pressure and body weight." (7)

All participants felt that a technological solution would be useful to them in the future. They replied as follows:

"Control of falls, fainting spells and medicine schedules" (7)

"Yes, telephone service and monitoring and the distress call." (8)

"Computer linked information with x-ray, image-guided surgery that al-ready exists." (9)

"Webcam, doctor's communication with patients at home. Computer and $x$-ray, other examinations and tests, even electrocardiogram." (10)

"Some device with an image and audio that we could operate with in moments of emergency, and to ask for help." (11)

"An emergency contact channel for the cell phone." (12)

In Brazil, several respondents said they had heard about healthcare technology. Some of the older people have a smartphone and they know basic mobile applications but do not combine them with much health care. Some elderly people attend free courses related to the use of phones and computers. Everyday security and communication with health care staff felt important. (Table 2).

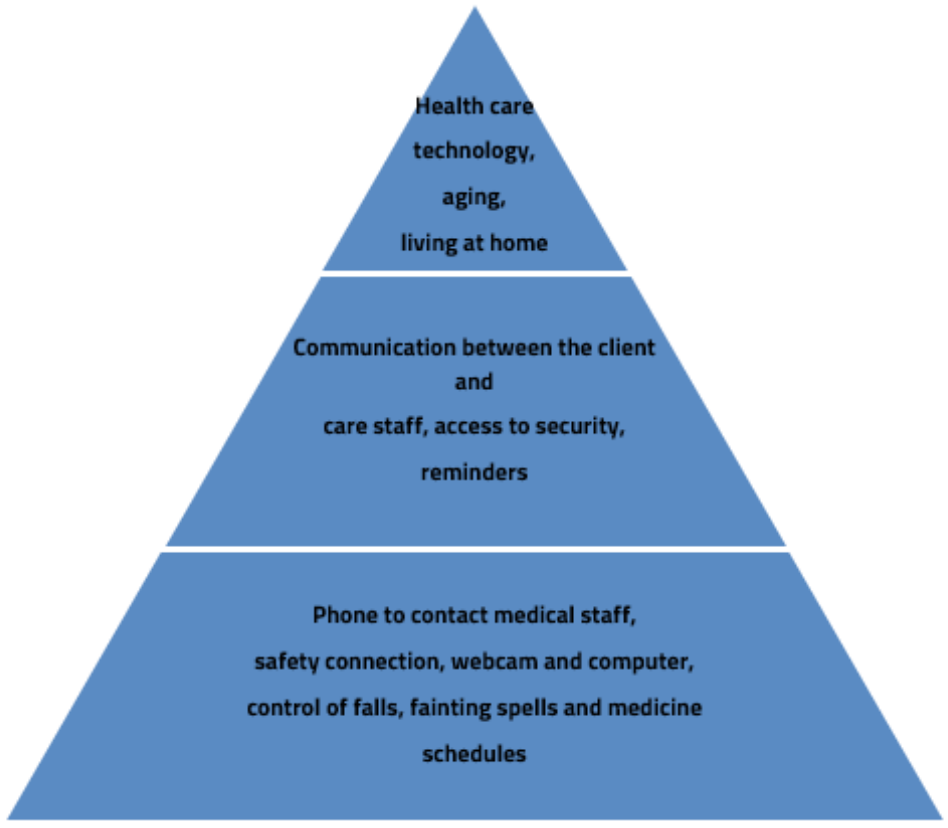

Table 2. Analysis of Brazil 


\section{CONCLUSIONS}

Considering ethical issues in research is very important because it concerns people. It is important for the researcher to know and act on ethical principles as it is the responsibility of every researcher. The researcher must be able to consider the ethical issues related to the research. For research to be ethically good, it must follow good scientific practice. Each study should be based on respect for human dignity and self-determination by allowing the participants to decide whether they want to participate in the research (HIRSJÄRVI; REMES; SAJAVAARA, 2009).

Before the interview, the participants were given a cover letter with in-formation of the authors of the study, the purpose of the research, the subject of the study and where the information would be used. The participants were asked for a written consent to the study.

In this study, ethics were considered by interviewing anonymously and using the gender and the age of the participants as background information. In Brazil, researchers never saw the participants as the interviews were conducted by a team of researchers from the University of Feevale. The responses received were treated confidentially.

The fact that the interviews have been done individually in the participants' own mother tongue in a peaceful environment adds to the reliability of the research. The questions have been approved by the Ethics Committee of the University. Responses to the interview have been studied and analyzed immediately after the interviews. The aim was to maintain reliability through a clear and concise, but comprehensive questionnaire. Good oral and written guidance on the study increased reliability in the study.

\section{DISCUSSION}

The purpose of the study was to find out the differences between the two countries regarding the technology knowledge of the elderly and the attractiveness of technology as home aids now or in the future. We decided to do a comparative study between Finland and Brazil because we were going to study at the University of Feevale and because we are at a very different level of technology development between the two countries and therefore the topic seemed very interesting. The research was carried out in Lahti, Finland and in Novo Hamburgo, Brazil. The aim of the study was to find out how older people experience health care technology, how much they know about it and what differences between them are in technology development. We chose ten years of age difference between countries because of different life expectancy estimates. 
Aging is global. Developed countries are aging at a slower pace than developing countries. Aging affects society in many ways. However, human activity should not be limited by age. It is certainly in everyone's interest that older people participate in society and bring their own experience of life and competence in their careers. It should also be remembered that people grow older as individuals, each with different levels and different rates. Social groups, regions and culture are just as important to older people as young people. The better the conditions for maintaining fitness and functioning in society are created already in the middle age, the better it supports aging, and when retiring it is not empty.

The need for services for the elderly has to be planned comprehensively. In both Finland and Brazil, it is very common for the elderly to stay in their homes for as long as possible. In Finland home care is intensified, while in Brazil there is little or no home care. The responsibility of the relatives in Brazil is more significant than in Finland. In Brazil, public health care is free, but the same quality cannot be guaranteed as in the private sector. That is why most Brazilians have insurance that allows access to quality care. It is possible for elderly people or people in home care, for example, to request visits by nursing staff, but visits cost a lot.

There are both municipal and private home care available in Finland. Public sector home care fees are determined by the income of the client or the couple. In addition, payouts are affected by the availability of support and running times for medical staff. In Finland, it is very common for elderly people or people in care to take municipal care and in most cases hospital treatment takes place in municipal hospitals and nursing homes.

In the healthcare sector, technology has been gaining ground in decades. In developed countries, technological solutions have taken a place in society faster. Technological solutions are being offered to health and wellness centers as well as to home care services. There are hardly any technological solutions available in underdeveloped countries, at least for all citizens, or they are very expensive.

The results of the research highlighted that in Brazil, technology is still far from being used in health care, and technology know-how and skills were mainly used for using a smartphone. In Finland, health care technology was known to be in use, but it was quite a stranger for the elderly. In Finland, the interviewees had tablets and smart phones, but health technology was not yet necessary. As a connecting factor for both countries, remote access to health care was noted, for example, a nurse being a well-known technological aid. In Finland, almost all interviewees also mentioned the safety telephone. In both target countries, the respondents felt that the technological tools related to safety were useful for their future. Access to knowledge is another very important age-motivating issue for technological solutions, which also emerged in both target countries. 
It can be concluded that the attitude towards technology is quite negative, especially in Finland. The negative attitude towards technology was mainly because it was feared to displace the right human contact at the time of trouble and was also considered expensive. There was hardly any knowledge of technology in Brazil, so we wonder that, for some reason, attitudes towards technology were not so negative. However, interviewees in both target countries saw technology as useful, for example, in monitoring their own health and as a means of communicating with health care.

In both target countries, older people feel that technology could be used to make everyday life easier, to create security and as means of communication. Even though the distance between is long, the idea about ageing and the challenges of ageing are not very different.

It would be expected that, as the younger population ages, technology will also grow. As it has been explore in the KÄKÄTE studies, the elderly in Finland are mainly accustomed to using only phones, it is to be expected that their interest and enthusiasm for technology is not the same as for younger generations who have had a strong technology (such as health technology) in their everyday and working life.

In this study, the number of people interviewed was rather small, so it would be interesting to go on studying the growth of health care technology and attitudes and opinions of older people towards technology and more people. It would be interesting to study even more the development of Brazilian technology in relation to Finland.

\section{REFERÊNCIAS}

COUNTRYECONOMY. Brazil-Life expectancy at birth, n.d. Disponivel em: <https://countryeconomy.com/ demography/life-expectancy/brazil>. Acesso em: 6 apr. 2019.

GARDEMEISTER, J. Sähköiset terveyspalvelut kotihoidossa. Disponivel em: https://thlproduction. storage.googleapis.com/2018/05/kandidaattitutkielma_gardemeister.pdf> Acesso em: 2 oct. 2018.

HEIKKINEN, E.; JYRKÄMÄ, J.; RANTANEN, T. Gerontologia. Helsinki: Duodecim, 2013.

HIRSJÄRVI, S.; REMES, P.;SAJAVAARA, P. Tutki ja kirjoita. Helsinki:Tammi, 2009

KORPELA, V. Ikäihmiset ja digitalisoituva yhteiskunta, 2018. Disponível em: https://jyx.jyu.fi/bitstream/ handle/123456789/57881/1/URN:NBN:fi:jyu-201805082493.pdf > Acesso em: 3 oct.2018.

PAIM, J.; TRAVASSOS, C.; ALMEIDA, C.; BAHIA, L.; MACINKO, J. The Brazilian health system: history, advances and challenges. The Lancet, 2011. Disponivel em: <http://dx.doi.org.ezproxy.hamk.fi/10.1016/ S0140-6736(11)60054-8 > . Acesso em: 5 Nov.2018. 


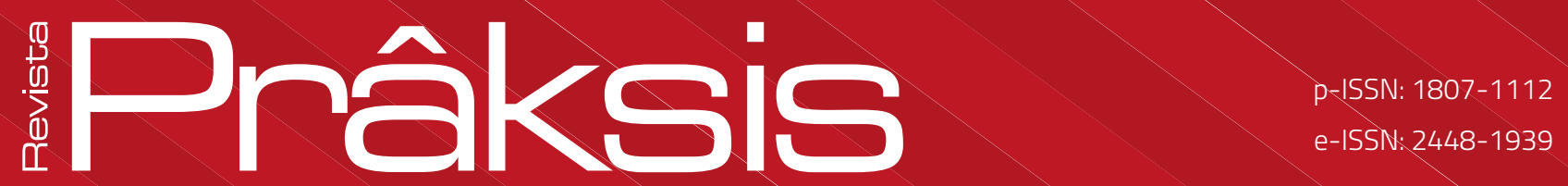

PEDRO DE MAGALHÃES, J.The biology of ageing, 2012. Disponivel em: https://pcwww.liv.ac.uk/ aging/ cup11_biology_of_ageing_introduction.pdf. Acesso em: 21 Dec.2018.

PIRHONEN, K. Teknologia sosiaali- ja terveydenhuollossa. Helsinki: Fioca, 2016.

TILASTOKESKUS. Elinajanodote. Findikaattori, 2015. Disponivel em: <https://findikaattori.fi/fi/46 >Acesso em: 20 seb. 2018.

ÄIJÖ, M.; TIKKANEN, P. Hyvä vanhuus. Menetelmiä aktiivisen arjen tukemiseen. Jyväskylä: PSKustannus, 2019. 